\title{
LONG-TERM RESULTS OF EXTREMITY SOFT TISSUE SARCOMAS LIMB-SPARING SURGERY AND RADIOTHERAPY
}

\author{
RESULTADOS DE LONGO PRAZO DE SARCOMAS DE \\ EXTREMIDADE: CIRURGIA E RADIOTERAPIA COM ESPUMA
}

\author{
Özlem Yetmen Dogan ${ }^{1}$, Didem Çolpan Oksuz ${ }^{2}$, Banu AtalaR ${ }^{3}$, Fazilet Oner Dincbas ${ }^{2}$ \\ 1. Saglık Bilimleri University, Kartal Dr Lutfi Kırdar Training and Research Hospital, Radiation Oncology Department, Istanbul, Turkey. \\ 2. Istanbul University-Cerrahpasa, Cerrahpasa Medical School, Radiation Oncology Department, Istanbul, Turkey. \\ 3. Acıbadem University, Maslak Hospital Radiation Oncology Department, Istanbul, Turkey.
}

\section{ABSTRACT}

Objective: To assess the prognostic factors and results of limb sparing surgery and postoperative radiotherapy (PORT) in patients with non-metastatic soft tissue sarcomas (STS) of the extremities. Methods: Between 1980-2007, 114 extremity-located STS treated with PORT were analyzed retrospectively. Tumors were mostly localized in the lower extremities (71,9\%). The median radiotherapy (RT) dose was 60.9 Gy. Chemotherapy was administered to $37.7 \%$ of the patients. Tumor sizes were between $3-26 \mathrm{~cm}$ (median $7 \mathrm{~cm}$ ). The three most frequent histological types included undifferentiated pleomorphic sarcoma (26.3\%), liposarcoma (25.4\%), and synovial sarcoma (13.2\%). The median follow-up for all patients was 60 months, and 81 months for survivors. Results: The 5- and 10-year local control (LC) rates were $77 \%$ and $70.4 \%$, respectively; actuarial survival rates for 5 and 10 years were $71.8 \%$ and $69.1 \%$, respectively. Increasing the dose above 60 Gy for all patients and the patients with positive margins demonstrated a clear benefit on 5-year LC ( $p=0.03$ and $p=0.04$, respectively). Based on multivariate analysis, the addition of chemotherapy and RT dose were independent prognostic factors for LC. A recurrent presentation significantly affects the disease-free survival. Conclusions: PORT for STS of the extremities provides good long-term disease control with acceptable toxicity in a multidisciplinary approach. Level of evidence III, Retrospective study.

Keywords: Soft tissue sarcomas. Extremities. Radiotherapy.

\section{RESUMO}

Objetivo: Avaliar os fatores prognósticos e os resultados da cirurgia poupadora de membro e radioterapia pós-operatória em pacientes com sarcomas de partes moles das extremidades. Métodos: Entre 1980 e 2007, 114 sarcomas de partes moles localizados em extremidades tratados com cirurgia poupadora de membro e radioterapia pós-operatória foram analisados restrospectivamente. Os tumores localizavam-se principalmente na região mais baixa (71,9\%). A dose média da radioterapia foi de 60,9 Gy. A quimioterapia foi usada em $37,7 \%$ dos pacientes. Os tamanhos do tumores estiveram entre 3 e $26 \mathrm{~cm}$ (mediana de $7 \mathrm{~cm}$ ). Os três tipos histológicos mais frequentes foram, respectivamente, sarcoma pleomórfico indiferenciado (26,3\%), lipossarcoma (25,4\%) e sarcoma sinovial (13,2\%). O tempo médio de acompanhamento para todos os pacientes foi de 60 meses e 81 meses para sobrevivente. Resultados: As taxas de controle local para 5 e 10 anos foram de $77 \%$ e 70,4\%, respectivamente, e as taxas de sobrevida foram de $71,8 \%$ e 69,1\%. Aumentar a dose acima de 60 Gy para todos os pacientes e para aqueles com margens positivas demonstrou claro benefício no controle local de 5 anos ( $p=0,03$ e $p=0,04$, respectivamente). Considerando a análise multivariada, a adição de quimioterapia e a dose de radioterapia foram fatores prognósticos independentes para controle local. Apresentação recorrente afetou significativamente a sobrevida livre da doença. Conclusões: A cirurgia poupadora de membro e radioterapia pós-operatória para sarcomas de partes moles das extremidades fornece bom controle da doença a longo prazo, com toxicidade aceitável na abordagem multidisciplinar. Nível de evidência III, Estudo retrospectivo.

Descritores: Sarcoma. Extremidades.Radioterapia.

Citation: Dogan ÖY, Oksuz DÇ, Atalar B, Dincbas FO. Long-term results of extremity soft tissue sarcomas limb-sparing surgery and radiotherapy. Acta Ortop Bras. [online]. 2019;27(4):207-11. Available from URL: http://www.scielo.br/aob.

\section{INTRODUCTION}

Soft tissue sarcomas (STS) are extremely rare neoplasms and account for $<1 \%$ of all malignancies. ${ }^{1}$ The main goal is to preserve the extremity function with good local and distant control with satisfactory survival rates. Since the 1980's conservative surgery combined with adjuvant radiotherapy improved local control, from
$78 \%$ to $91 \%$. Many previous studies have shown that the results with limb sparing surgery and postoperative radiotherapy are similar with radical surgery- alone and with less morbidity. ${ }^{2,3}$ Especially in high-grade sarcomas, the role of adjuvant radiotherapy in terms of conservative approach has been proven in randomized trials. ${ }^{4,5}$

All authors declare no potential conflict of interest related to this article.

This work was conduced at Istanbul University-Cerrahpasa, Cerrahpasa Medical School, Radiation Oncology Department, Istanbul, Turkey. Correspondence: Ozlem Yetmen Dogan. Kartal Dr Lutfi Kırdar Training and Research Hospital. Şemsi Denizer Cad. E-5 Karayolu Cevizli Mevkii, Kartal, Istanbul, Turkey. 34890. dryetmen@gmail.com 
Grade is the most important predictor for both overall and disease-free survival. The other prognostic factors for survival are known to be age, tumor size and tumor location, type of surgery and resection margin. ${ }^{6}$ The relationship between local control and survival is controversial. Some authors reported that, there is no relation between them, however, Lewis et al. found a strong correlation with local control and metastasis and tumor mortality. ${ }^{7}$

The present study was performed to evaluate long term results of limb-sparing surgery and post-operative radiotherapy with or without chemotherapy among patients with non-metastatic STS of the extremities and compare our results with the literature results. Acute and late radiation related toxicities were analyzed.

\section{MATERIALS AND METHODS}

\section{Patient and tumor characteristics}

Between 1980-2007, a total of 386 patients were treated with radiotherapy for soft tissue sarcomas at Istanbul University-Cerrahpasa, Cerrahpasa Medical School, Radiation Oncology Department,Istanbul. Patients who had non-extremity STS or who received prior chemotherapy and radiotherapy to the local site or who had previous or concurrent malignancy and patients with distant metastasis and specific histologic subgroups, including, rhabdomyosarcoma, extraosseaus Ewing, primitive neuroectodermal tumor or dermatofibrosarcoma protuberans were not included in this study. Of the remaining 114 patients with extremity located soft tissue sarcomas who were treated with postoperative radiotherapy in our department, were analyzed retrospectively.

All 114 patients were treated with limb-sparing surgery followed by postoperative chemo/radiotherapy after discussed at the weekly multidisciplinary bone and STS tumor board. All the pathological specimens were received and revised by our sarcoma pathologist. Postoperative radiotherapy was performed to patients who had factors associated with an increased risk of recurrence such as high grade tumor, large tumor, close or positive surgical margins. Tumor size was divided in three groups: $\leq 5 \mathrm{~cm},>5-15 \mathrm{~cm}$ or $\geq 15$ $\mathrm{cm}$. The tumor grade was defined as high; grade III, intermediate or low; grade II-I. The superficial tumor means that tumor was located above the superficial facia, and the deep tumor means that if the tumor involves the facia or located beneath the facia. Margin status was called involved; that means microscopically involved surgical margin, marginal margin; surgical margin was in pseudo-capsule or reactive zone, wide margin; tumor was in the compartmental en block resection or radical margin; tumor was in the extracompartmentalen block entire compartment.

Sixty (53\%) were male, 54 (47\%) were female. Median age was 44 years (range, 15-82). Tumor size was defined as the maximum diameter of the tumor during pathologic analysis. Tumor size was between $3-26 \mathrm{~cm}$ (median $7 \mathrm{~cm}$ ). Tumors were mostly localized in the lower extremity $82(71,9 \%)$.Five (4\%) low grade liposarcoma patients were treated with post operative radiotherapy treatment because their tumor location was in the hand and foot with surgical margin was positive and re-excision was not possible due to location of the tumor. The tumor characteristics are summarized in Table 1.

\section{Treatment}

Immobilization instruments were used for all of the patients as required. Treatment was delivered with $\mathrm{Co}^{60}$ machine or 4-6 MV linear accelerators. A shrinking-field technique was used. The limits of initial field margins varied but there were at least $5 \mathrm{~cm}$ from the tumor bed and the scar. The boost target volume was consisting of the tumor bed and incision scar with $2 \mathrm{~cm}$ margin. Treatment was delivered 45-50 Gy to initial field, 60-70 Gy booster dose to the tumor volume in 1.8-2Gy/fractions/day, 5 days/week. The median total tumor dose was 60,9Gy (44-70Gy).The median
Table 1. The characteristics of sarcomas

\begin{tabular}{|c|c|c|}
\hline & $\begin{array}{l}\text { Patients } \\
\text { (n) }\end{array}$ & $(\%)$ \\
\hline Median age & $44(15-82)$ & \\
\hline \multicolumn{3}{|l|}{ Age } \\
\hline$<50$ & 68 & 59 \\
\hline$\geq 50$ & 46 & 41 \\
\hline \multicolumn{3}{|l|}{ Gender } \\
\hline Female & 54 & 48 \\
\hline Male & 60 & 53 \\
\hline Median Tumor Size & $7 \mathrm{~cm}$ & range $3-26 \mathrm{~cm}$ \\
\hline \multicolumn{3}{|l|}{ Tumor location } \\
\hline Upper extremity & 32 & 28 \\
\hline Lower extremity & 82 & 72 \\
\hline \multicolumn{3}{|l|}{ Stage } \\
\hline la & 9 & 8 \\
\hline $\mathrm{Ib}$ & 12 & 11 \\
\hline Ila & 44 & 39 \\
\hline $\mathrm{llb}$ & 23 & 20 \\
\hline IIIa & 10 & 9 \\
\hline IIIb & 16 & 14 \\
\hline \multicolumn{3}{|l|}{ Tumor size } \\
\hline$\leq 5 \mathrm{~cm}$ & 41 & 36 \\
\hline $5-<15 \mathrm{~cm}$ & 44 & 39 \\
\hline$\geq 15 \mathrm{~cm}$ & 29 & 25 \\
\hline \multicolumn{3}{|l|}{ Histopathological diagnosis } \\
\hline Undifferentiated pleomorphic sarcoma & 30 & 27 \\
\hline Liposarcoma & 29 & 25 \\
\hline Synovialcell sarcoma & 15 & 13 \\
\hline Fibrosarcoma & 12 & 10 \\
\hline Others & 28 & 25 \\
\hline \multicolumn{3}{|l|}{ Grade } \\
\hline Grade I+II & 13 & 11 \\
\hline Grade III & 101 & 89 \\
\hline \multicolumn{3}{|l|}{ Surgical margin } \\
\hline Involved & 25 & 22 \\
\hline Marginal & 72 & 63 \\
\hline Wide & 12 & 11 \\
\hline Unknown & 5 & 4 \\
\hline
\end{tabular}

radiotherapy time was 49 days (31-95 days). Chemotherapy was administered to $43(37.7 \%)$ patients with high grade and large tumors. Chemotherapy scheme was consisted of doxorubicine $75 \mathrm{mg} / \mathrm{m}^{2}$ (D1-3), ifosfamide $2 \mathrm{mg} / \mathrm{m}^{2}$ with $2 \mathrm{mg} / \mathrm{m}^{2}$ mesna, and given in different combinations in 6 cycles.

\section{Follow-up}

After treatment all patients were followed regularly with a physical examination every 3 months for 2 years, every 6 months between 3 and 5 years and yearly thereafter. Recurrent disease was histologically confirmed. All patients with recurrent disease were discussed for their treatment schedule at our hospitals sarcoma board.

\section{Prognostic Factors and Statistical methods}

Prognostic factors that may influence local control, disease-free survival and overall survival were subjected to univariate and multivariate analysis. Local control, disease-free survival and overall survival rates were calculated using the Kaplan-Meier method. All time-to-failure end points were calculated from the date of diagnosis. Overall survival was measured from after the diagnosis of sarcoma to the time of last follow-up or date of death. Univariate and multivariate analysis of prognostic factors were performed using log-rank and Cox regression models, respectively. A p value $<0.05$ value was accepted as statistically significant. 


\section{RESULTS}

\section{Local control}

At the time of evaluation, 26 (23\%) patients had local failures following postoperative radiotherapy. Of these, 14 patients died of progressive and metastatic disease; the others were still alive at last follow-up. The median time to local progression was 53 months (range of 3-270 months). The 5- and 10-year local control rates were 77\%, 70\% respectively. (Figure 1) On the univariate analysis; local control rate was better in patients with tumor located in the lower extremity than in upper extremity, but the difference was not significant $(p=0.07)$. Local control rate was significantly worse in patients who received less than 60 Gy radiotherapy dose $(p=0.03)$. The surgical margin positive patients were reanalyzed, there was a significant benefit when the dose was > 60Gy $(p=0.04)(62.8 \% \& 79.4 \%)$. Patients who were treated with chemo-radiotherapy had better local control rate $(p=0.08)$. (Table 2$)$ In multivariate analysis, radiotherapy total dose, chemotherapy were the independent prognostic factors for local control. (Table 3)

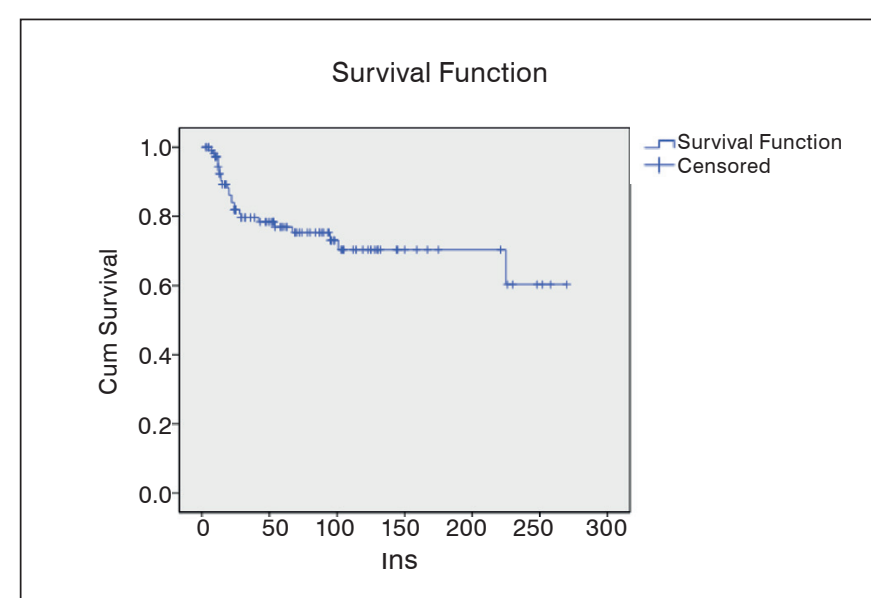

Figure 1. Five-year local control rates for all patients.

Table 2. Univariate analysis of prognostic factors for Local Control (LC), Disease-free Survival(DFS) and Actuarial Survival (ACS). (CHT: Chemotherapy; $\mathrm{RT}$ : radiotherapy).

\begin{tabular}{c|c|c|c|c|c|c}
\hline & \multicolumn{2}{|c|}{ LC } & \multicolumn{2}{c|}{ DFS } & \multicolumn{2}{c}{ ACS } \\
\hline & 5 year $\%$ & $\mathrm{p}$ & 5 year $\%$ & $\mathrm{p}$ & 5 year \% & $\mathrm{p}$ \\
\hline Extremity & & & & & & \\
\hline Upper & $64.6 \%$ & 0.07 & $57.7 \%$ & 0.7 & $70.4 \%$ & 0.4 \\
\hline Lower & $81.5 \%$ & & $60.8 \%$ & & $72.1 \%$ & \\
\hline Dose & & & & & & \\
\hline$<60$ Gy & $62.2 \%$ & 0.03 & $58.7 \%$ & 0.4 & $76.9 \%$ & 0.8 \\
\hline$\geq 60$ Gy & $79.4 \%$ & & $60.2 \%$ & & $75.3 \%$ & \\
\hline CHT & & 0.08 & & & & \\
\hline$(-)$ & $70.3 \%$ & & $54.5 \%$ & 0.2 & $60.2 \%$ & 0.2 \\
\hline$(+)$ & $80.8 \%$ & & $63.1 \%$ & & $77.9 \%$ & \\
\hline Gender & & & & & & \\
\hline Male & $71.6 \%$ & 0.09 & $52.8 \%$ & 0.07 & $64.2 \%$ & 0.04 \\
\hline Female & $83 \%$ & & $67.2 \%$ & & $81.3 \%$ & \\
\hline Grade & & & & & & \\
\hline I & $80.5 \%$ & 0.3 & $66.4 \%$ & 0.2 & $75.8 \%$ & 0.7 \\
\hline II & $75.1 \%$ & & $55.7 \%$ & & $77.7 \%$ & \\
\hline III & $63.9 \%$ & & $55.6 \%$ & & $62.2 \%$ & \\
\hline Stage & & & & & & \\
\hline I & $80.1 \%$ & 0.3 & $65.7 \%$ & 0.3 & $75.2 \%$ & 0.7 \\
\hline II & $76.2 \%$ & & $53.4 \%$ & & $74.8 \%$ & \\
\hline III & $63.9 \%$ & & $50.5 \%$ & & $62.2 \%$ & \\
\hline & & & & & \\
\hline
\end{tabular}

\section{Disease-free survival}

Distant metastasis was noted in $27 \%$ of the patients; 12 of them had also local failure. The most common sites of distant metastases were the lung (20\%) and the bone (5\%). Disease-free survival rates for 5 and 10 years were $60 \%$ and $52 \%$ respectively. (Figure 2) The disease-free survival rates were slightly better for the female patients $(p=0.07)$. (Table 2)

\section{Actuarial survival}

A total of $33(28,9 \%)$ patients died during follow-up. Of these, 31 were associated with disease progression (including 3 from local-regional failure, 17 from distant metastasis and 11 from both). A further 2 patients died from an unknown cause. The median follow-up time for living patients was 81 months (12-270 months). Actuarial survival rates for 5 and 10 years were $72 \%$ and $70 \%$ respectively. (Figure 3 )

Table 3. Multivariate analysisof prognostic factorsfor Local Control (LC), Disease-free Survival (DFS) and Actuarial Survival (ACS).

\begin{tabular}{|c|c|c|c|}
\hline & LC & DFS & ACS \\
\hline & $\mathrm{HR}(95 \% \mathrm{Cl})$ & $\mathrm{HR}(95 \% \mathrm{Cl})$ & $\mathrm{HR}(95 \% \mathrm{Cl})$ \\
\hline \multicolumn{4}{|c|}{ Extremity } \\
\hline Lower & $0.080 .488(0.218-1.092)$ & $0.90 .966(0.493-1.895$ & $0.80 .926(0.410-2.092)$ \\
\hline Upper & 1 & 1 & 1 \\
\hline \multicolumn{4}{|l|}{ Dose } \\
\hline$<60 G y$ & 0.0091 & $0.10 .581(0.262-1.292)$ & 0.91 .029 (0.353-2.999) \\
\hline$\geq 60$ Gy & $0.291(0.116-0.730)$ & 1 & 1 \\
\hline \multicolumn{4}{|l|}{ CHT } \\
\hline$(-)$ & $0.03 \quad 1$ & $1.500(0.820-2.744)$ & $0.11 .421(0.689-2.931)$ \\
\hline$(+)$ & $0.423(0.191-0.935)$ & 1 & \begin{tabular}{|c|}
1 \\
\end{tabular} \\
\hline
\end{tabular}

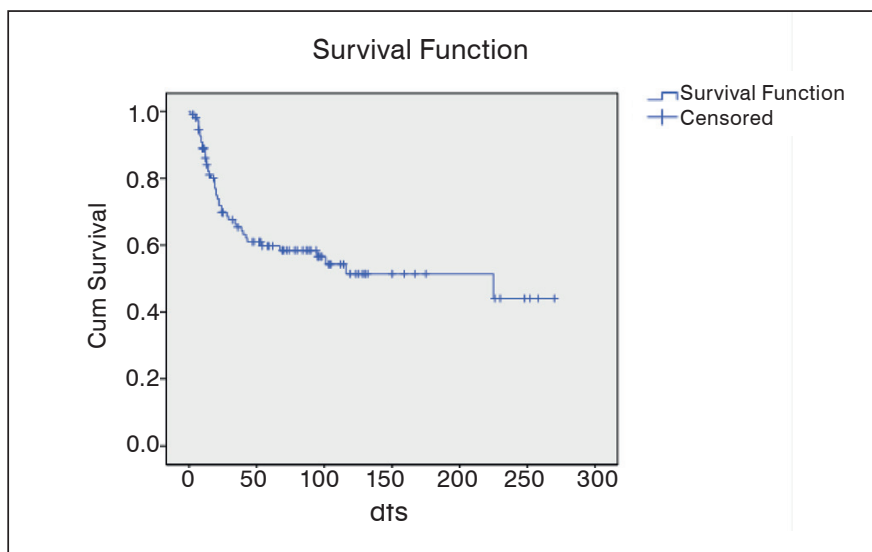

Figure 2. Five-year disease free control rates for all patients.

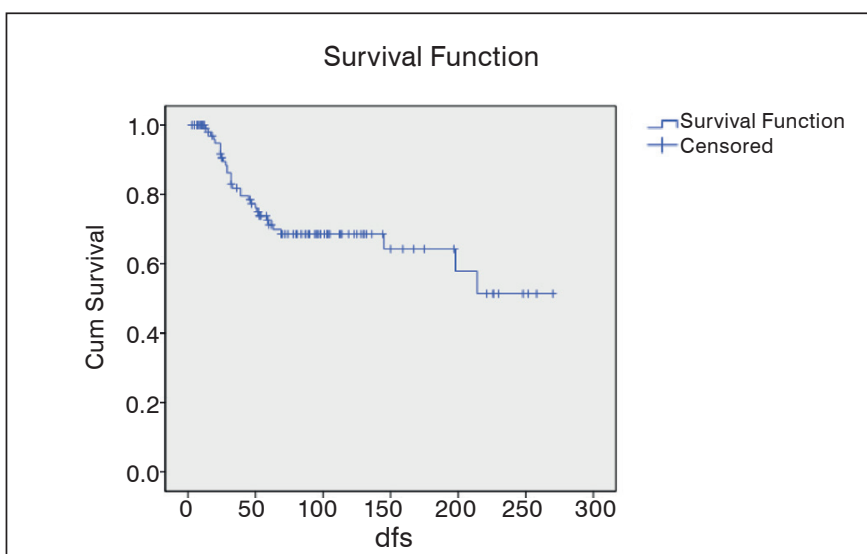

Figure 3. Five-year Actuarial control rates for all patients. 
On univariate analysis, the actuarial survival rate was significantly higher in female than male patients $(p=0.04)$. (Table 2$)$ In addition, we did not find any independent significant prognostic factor on multivariate analysis. (Table 3)

\section{Complications}

Acute and late side effects were scored according to RTOG and EORTC criteria. Among the 92 patients, acute radiation effects were documented in 54 patients. Grade I acute skin reactions were observed in 38 patients and grade II in 16 patients. Radiation fibrosis (45.6\%) was the most common late side effect. Deep vein thrombosis had occurred in one patient, 9 patients had chronic oedema, 6 patients had lymphangitis and 1 patient had bone fracture.

\section{DISCUSSION}

Nowadays, the treatment of soft tissue tumors of the extremities; except for a small rate of cases, is limb sparing therapy. The purpose is to protect quality of life and function while maintaining local control. While local control rates is not at the desired levels with limb-sparing surgery alone, adjuvant radiotherapy is offered in addition to limb sparing surgery to improve the results. The results showed that combining these two treatment methods achieved the same success with radical surgery alone. ${ }^{8}$ The first prospective, randomized study comparing amputation with limb-sparing surgery and radiotherapy showed similar disease-free and overall survival rates. ${ }^{3}$ These results were supported by randomized trials, especially in high-grade tumors. ${ }^{9}$ Both pre- and post-operative radiotherapy are considered to be standard approaches for most intermediate or high grade soft tissue sarcomas. The addition of radiotherapy to surgery allows preservation of function with similar local control rates, and survival, to radical resection (i.e. compartmental excision/amputation). ${ }^{8}$ The majority of patients with low-grade tumors will not require radiotherapy. However, it should be considered for those with large, deep tumors with close or incomplete margins of excision, in whom re-excision is not possible, especially if adjacent to vital structures that could limit further surgery in the future. Patients who have undergone a compartmental resection or amputation do not require adjuvant radiotherapy assuming that the margins are clear. If pre-operative radiotherapy is used there is a slightly higher incidence of post-operative morbidity including acute wound healing problems. Approaches which include the use of local or free flaps might be advantageous to avoid wound complications. Free flaps may reduce the risk of postoperative wound breakdown, minimize the dead space, and reconstruct the defect. A two team surgical approach (resection and reconstruction) reduces the operative time. Pre-operative radiotherapy may be less appropriate in cases where wound healing is more likely to be problematic, such as proximal thigh/groin or axillary locations. In addition, if a patient has a rapidly growing, painful tumor early surgery may be preferred. For certain radiosensitive histological subtypes, such as myxoid liposarcoma, pre-operative radiotherapy may be particularly advantageous, given the degree of tumor shrinkage that can be achieved. Pre-operative RT was significantly associated with an increased likelihood for negative surgical margins, thereby providing evidence for the underlying hypothesis that preoperative RT allows for sterilization of the surgical margins and increases the likelihood of achieving an oncological optimal resection.

Local recurrence rate varies between 9\%-24\% in the literature. Prognostic factors were evaluated in several studies. ${ }^{10-14}$ The anatomic location of an extremity soft tissue tumor influences local control. Five year local control rates were shown to be significantly better in proximal localized and lower extremity tumors. ${ }^{10,11}$ Alektiar also reported lower control rates on the upper extremity, they concluded that upper extremity localization was more difficult to obtain wide surgical margin..$^{12}$ In the present study, the number of the patients with positive surgical margin were more (44\%) on the upper extremity than lower extremity (34\%) supporting the results of Alektiar et. al.The rate of local control was found to be better in patients with tumors located in the proximal lower extremity than the patients with proximal upper extremity tumors $(p=0.07)$. Histological differentiation has been reported to be an important prognostic factor in several studies. Singer et. al. reported better survival rates in patients with low grade tumors than high grade tumors, although it did not influence the local control rates. ${ }^{13}$ In addition, some studies demonstrated that high grade was the only factor found to be associated with an increased risk of metastatic recurrence. ${ }^{14}$ In our study, patients with high grade tumors had also worse survival rates compared to patients with low grade tumors, but the difference was not statistically significant.

Most studies have agreed that surgical margin was one of the strongest negative prognostic value for local control. ${ }^{9,15}$ Incomplete resection had found to be the most significant factor on local recurrence and survival in our previous analysis of our patients with extremity, trunk and head-neck STS treated before 1995, however this significance disappeared in the current series. ${ }^{16}$ The adequate distance from the tumor for accepting as negative margin is variable. Helsinki University study demonstrates that surgical margins $>2.5 \mathrm{~cm}$ from the tumor were associated with improved local control. They reported that local control rates were $89.2 \%, 85.9 \%$ and $83.3 \%$,respectively, when combined with adjuvant RT, with the negative margins of at least $2.5 \mathrm{~cm}, 2 \mathrm{~cm}$ and 1 $\mathrm{cm} .{ }^{17}$ In addition several series agreed on that postoperative RT to the patients with close margins has improved local control. ${ }^{16,18}$ Recently, several centers reported that higher irradiation dose should be given in order to improve local control for extremities STS patients with positive margins. Zagars et al. reported improved local control with doses $\geq 64$ Gy for the patients with close or positive margin in the MD Anderson Cancer Center study. ${ }^{15}$ We found similar correlation between the dose above 60Gy and local control for all patients with positive margins.

Data supporting chemotherapy for extremity STS is controversial. Patients with deeply located, high-grade and $>5 \mathrm{~cm}$ tumors have $60 \%$ chance of developing metastatic disease. ${ }^{19}$ Sarcoma Meta-Analysis Collaboration meta-analysis reported that adjuvant chemotherapy increases disease-free survival rate but does not affect overall survival rate. ${ }^{20}$ In the present study, chemotherapy was given to patients with poor prognostic factors and significantly increased the local control on multivariate analysis; however, it was not reflected to the disease-free survival and actuarial survival rates.

\section{CONCLUSION}

Limb-sparing surgery with postoperative RT for extremity located STS provides excellent local control and high survival rates with acceptable toxicity and good functional outcome. In the present study although the incidence of large tumor size and marginal resections were high, local failure rate in these patients was comparable with the literature. While this is a retrospective analysis with heterogeneous patient-tumor characteristics, we found that radiotherapy dose and chemotherapy administration were the important factors to improve treatment results. Considering at the high failure rate in the patients who were previously operated in different centers, referral of these patients to the centers dealing with STS for adjuvant therapy is highly recommended.

AUTHORS' CONTRIBUTIONS: Each author contributed individually and significantly to the development of the manuscript. ÖYD (0000-0002-2733-0427) * writing, revision, and data analysis; BA (0000-0001-8435-8074)*; surgeries, data analysis, and writing of articles; DÇÖ (0000-0003-4947-0428** statistical analysis and review of the article; FÖD (0000-0002-4764-9419)*: writing and review of manuscript and contributed the entire intellectual concept of the article. *ORCID (Open Researcher and Contributor ID). 


\section{REFERENCES}

1. Liebel SA, Tranbaugh RF, Wara WM, Beckstead JH, Bovill EG, Phillips TL. Soft tissue sarcomas of the extremities: Survival and patterns of failure with conservative surgery and postoperative irradiation compared to surgery alone. Cancer. 1982;50(6):1076-83.

2. Lindberg RD, Martin RG, Romsdahl MM, Barkley HT Jr. Conservative surgery and postoperative radiotherapy in 300 adults with soft-tissue sarcomas. Cancer. 1981;47(10):2391-7.

3. Rosenberg SA, Tepper J, Gladstein E, Costa J, Baker A, Brennan M, et al. The treatment of soft tissue sarcomas of the extremities: Prospective randomized evaluations of limb sparing surgery plus radiation therapy compared with amputation and the role of adjuvant chemotherapy. Ann Surg. 1982;196(3):305-15.

4. Pisters PW, Harrison LB, Leung DH, Woodruff JM, Casper ES, Brennan MF. Long term results of a prospective randomized trial of adjuvant brachytherapy in soft tissue sarcoma. J Clin Oncol. 1996;14(3):859-68.

5. Yang JC, Chang AE, Baker AR, Sindelar WF, Danforth DN, Topalian SL, et al. Randomized prospective study of the benefit of adjuvant radiation therapy in the treatment of soft tissue sarcomas of the extremity. J Clin Oncol. 1998;16(1):197-203.

6. Toulmonde M, Le Cesne A, Mendiboure J, Blay JY, Piperno-Neumann S, Chevreau $\mathrm{C}$, et al. Long-term recurrence of soft tissue sarcomas: Prognostic factors and implications for prolonged follow-up. Cancer. 2014 Oct 1;120(19):3003-6. doi: 10.1002/cncr.28836. Epub 2014 Jun 18.

7. Lewis JJ, Brennan MF. Soft tissue sarcomas. Curr Probl Surg. 1996;33(10):817-72.

8. Yang JC, Chang AE, Baker AR, Sindelar WF, Danforth DN, Topalian SL, et al. Randomized prospective study of the benefit of adjuvant radiation therapy in the treatment of soft tissue sarcomas of the extremity. J Clin Oncol. 1998;16(1): 197-203.

9. Schreiber D, Rineer J, Katsoulakis E, Sroufe RL, Lange CS, Nwokedi E, et al. Impact of postoperative radiation on survival for high-grade softtissuesarcoma of the extremities after limb sparing radical resection. Am J Clin Oncol. 2012;35(1):13-7.
10. Pisters PW, Leung DH, Woodruff J, Shi W, Brennan MF. Analysis of prognostic factors in 1,041 patients with localized soft tissue sarcomas of the extremities. J Clin Oncol. 1996;14(5):1679-89.

11. Alektiar KM, Velasco J, Zelefsky MJ, Woodruff JM, Lewis JJ, Brennan MF. Adjuvant radiotherapy for margin-positive high-grade soft tissue sarcoma of the extremity. Int J Radio Oncol Biol Phys. 2000;48(4):1051-8.

12. Alektiar KM, Brennan MF, Singer S. Influence of site on the therapeutic ratio of adjuvant radiotherapy in soft-tissue sarcoma of the extremity. Int J Radiat Oncol Biol Phys. 2005;63(1):202-8

13. Singer S, Corson JM, Gonin R, Labow B, Eberlein T. Prognostic factors predictive of survival and local recurrence for extremity soft tissue sarcoma. Ann Surg. 1994;219(2):165-73.

14. Baroudi MR, Ferguson PC, Wunder JS, Isler MH, Mottard S, Werier JA, et al. Forearm soft tissue sarcoma: Tumors characteristics and oncologic outcomes following limb salvage surgery. J Surg Oncol. 2014 Nov;110(6):676-81. doi: 10.1002/jso.23686. Epub 2014 Jun 9.

15. Zagars GK, Ballo MT. Significance of dose in postoperative radiotherapy for soft tissue sarcoma. Int J Radiat Oncol Biol Phys. 2003;56(2):473-81.

16. Cakır S, Dincbas FO, Uzel O, Koca S, Okkan S. Multivariate analysis of prognostic factors in 75 patients with soft tissue sarcoma. Radiother Oncol. 1995;37(1):10-6.

17. Sampo M, Tarkkanen M, Huuhtanen R, Tukiainen E, Böhling T, Blomqvist C. Impact of the smallest surgical margin on local control in soft tissue sarcoma. Br J Surg. 2008;95(2):237-43.

18. Trovik CS, Bauer HC, Berlin O, Tukiainen E, Erlanson M,Gustafson P, et al. Local recurrence of deep-seated, high grade, soft tissue sarcoma:459 patients from the Scandinavian Sarcoma Group Register. Acta Ortop Scand. 2001;72(2):160-6.

19. Wunder JS, Healey JH, Davis AM, Brennan MF. A comparison of staging system for localized extremity soft tissue sarcomas. Cancer. 2000;88(12):2721-30.

20. Anonymous. Adjuvant chemotherapy for localized resectable soft tissue sarcoma of adults: Meta-analysis of individual data. Sarcoma Meta-analysis Collaboration. Lancet. 1997;350(9092):1647-54. 